\title{
Pentingnya Kinerja Perawat yang Efektif dalam Pelaksanaan \\ Pendokumentasian Asuhan Keperawatan \\ Novi Pratiwi \\ novipratiwi211@gmail.com
}

\begin{abstract}
Abstrak
Salah satu tenaga kesehatan di rumah sakit yang memiliki peranan cukup besar dalam peningkatan mutu pelayanan kesehatan adalah perawat. Perawat dalam melaksanakan asuhan keperawatan dituntut untuk memiliki kemampuan intelektual, interpersonal, kemampuan teknis dan moral. Mutu asuhan keperawatan dapat tergambar dari dokumentasi proses keperawatan. Pendokumentasian merupakan suatu kegiatan pencatatan, pelaporan atau merekam suatu kejadian serta aktivitas yang dilakukan dalam bentuk pemberian pelayanan yang dianggap penting dan berharga. Tidak lengkapnya dokumentasi asuhan keperawatan berkaitan dengan kinerja perawat dalam melaksanakan pendokumentasian. Maka, tujuan dari penulisan ini adalah untuk mengetahui tentang pentingnya kinerja perawat yang efektif dalam palaksanaan pendokumentasian asuhan keperawatan.
\end{abstract}

Kata kunci : Perawat, pendokumentasian asuhan keperawatan, kinerja.

\section{Latar Belakang}

Rumah sakit merupakan sarana kesehatan yang salah satu fungsinya menyelenggarakan pelayanan dan asuhan keperawatan yang merupakan bagian dari sistem pelayanan kesehatan dengan tujuan memelihara kesehatan masyarakat seoptimal mungkin. Mutu pelayanan kesehatan di rumah sakit sangat dipengaruhi oleh tenaga kesehatan yang bekerja di rumah sakit tersebut. Salah satu tenaga kesehatan di rumah sakit yang memiliki peranan cukup besar dalam peningkatan mutu pelayanan kesehatan adalah perawat.

Salah satu hal yang dapat dilakukan untuk meningkatan pelayanan kesehatan yang bermutu adalah meningkatkan kompetensi perawat. Perawat dalam melaksanakan asuhan keperawatan dituntut untuk memiliki kemampuan intelektual, interpersonal, kemampuan teknis dan moral. Hal ini dilakukan perawat selama 24 jam sehari dalam melaksanakan asuhan keperawatan yaitu pengkajian, diagnosa keperawatan, perencanaan, implementasi dan evaluasi.

Mutu asuhan keperawatan dapat tergambar dari dokumentasi proses keperawatan. Dokumentasi dalam keperawatan memegang peranan penting terhadap segala macam tuntutan 
masyarakat yang semakin kritis dan mempengaruhi kesadaran masyarakat akan hak-haknya dari suatu unit kesehatan. Setiap pelaksanaan proses keperawatan, perawat akan selalu melakukan pencatatan atau disebut dengan pendokumentasian, mulai dari pengkajian, diagnosa, perencanaan, pelaksanaan dan evaluasi. Peraturan departemen kesehatan menyatakan bahwa tenaga perawat dalam melaksanakan asuhan keperawatan kepada pasien, didokumentasikan secara benar dan tepat serta disimpan pada rekam medis asuhan keperawatan, sehingga tercipta sistem informasi rumah sakit yang dapat dipercaya atau akurat.

Dokumentasi merupakan aspek penting dari praktik keperawatan karena berisi catatancatatan yang berguna untuk komunikasi, tagihan finansial, edukasi, pengkajian, riset, audit dan dokumentasi legal. Pendokumentasian merupakan suatu kegiatan pencatatan, pelaporan atau merekam suatu kejadian serta aktivitas yang dilakukan dalam bentuk pemberian pelayanan yang dianggap penting dan berharga. Pendokumentasian yang tidak dilakukan dengan lengkap dapat menurunkan mutu pelayanan keperawatan karena tidak dapat mengidentifikasi sejauh mana tingkat keberhasilan asuhan keperawatan yang telah diberikan.

Pendokumentasian ini berkaitan dengan kinerja perawat dalam melaksanakan tugasnya. Tidak lengkapnya dokumentasi asuhan keperawatan berkaitan dengan kinerja perawat dalam melaksanakan pendokumentasian. Mengingat pentingnya pendokumentasian ini sehingga perlu diketahui mengenai pentingnya kinerja perawat yang efektif dalam melaksanakan pendokumentasian asuhan keperawatan.

\section{Metode}

Metode yang dilakukan dalam penulisan ini adalah metode kepustakaan yaitu dengan melakukan peninjauan, mengumpulkan data-data dan menganalisisnya yang diperoleh dari buku, e-book, jurnal-jurnal terkini ataupun sumber informasi lainnya yang memuat informasi pembahasan tentang kinerja perawat yang efektif dalam palaksanaan pendokumentasian asuhan keperawatan untuk menjaga kesejahteraan pasien di rumah sakit. Pengolahan data dilakukan mulai dari menganalisis isi buku dan jurnal atau sumber informasi lainnya yang berhubungan dengan kinerja perawat yang efektif dalam palaksanaan pendokumentasian asuhan keperawatan hingga kesimpulan dari penulis.

\section{Hasil}

Hasil penelitian yang dilakukan oleh Saragih (2018), menunjukkan bahwa kinerja perawat pelaksana dalam melakukan pendokumentasian asuhan keperawatan di Ruang Rawat Inap Rumah Sakit Umum Sari Mutiara Medan mayoritas yaitu $(69,8 \%)$ responden memiki 
kinerja baik dalam melakukan pendokumentasian asuhan keperawatan. Hal ini diperoleh berdasarkan lembar observasi penelitian yang di lakukan peneliti terhadap asuhan keperawatan yang dibuat oleh perawat pelaksana didapatkan bahwa kategori yang ada ditulis/diisi oleh perawat dalam asuhan keperawatan yang paling dominan yaitu pada diagnosa keperawatan berdasarkan masalah pasien sebanyak $(76,7 \%)$ dan $(72,1 \%)$ berkas catatan keperawatan disimpan sesuai dengan ketentuan yang berlaku.

Kinerja perawat pelaksana dalam pendokumentasian askep yang baik sebanyak 30 orang $(69,8 \%)$ sedangkan 13 orang $(30,2 \%)$ kurang baik. Hal ini sejalan dengan penelitian yang dilakukan Leli siswana (2010) tentang hubungan peran supervisi kepala ruangan terhadap kinerja perawat pelaksana di Rumah Sakit Umum Daerah Petala Bumi didapatkan bahwa peran supervisi kepala ruangan yang sangat baik sebanyak 21 orang $(16,2 \%)$, persentase ini ternyata lebih tinggi daripada peran supervisi kepala ruangan yang kurang baik sebanyak 10 orang $(14,8 \%)$.

Pendokumentasian asuhan keperawatan yang tidak baik dapat dikaitkan dengan banyak variabel, antara lain motivasi kerja, stres kerja, beban kerja, gaya kepemimpinan, hubungan antar manusia kurang harmonis, supervisi dari atasan tidak efektif dan mungkin saja kejenuhan kerja.

Hasil penelitian Siswanto (2013) menunjukkan bahwa sebagian besar perawat yang mempunyai beban kerja tinggi tidak melakukan pendokumentasian dengan lengkap. Hal ini menunjukkan bahwa terdapat hubungan yang bermakna antara beban kerja dengan kelengkapan pendokumentasian asuhan keperawatan. Dari semua perawat yang mempunyai beban kerja tinggi tersebut hanya 16,7\% yang melakukan pendokumentasian dengan lengkap.

Hasil penelitian tersebut sejalan dengan pendapat Ilyas (2012) bahwa beban kerja perawat yang tinggi memengaruhi produktivitas kinerja perawat termasuk kegiatan pendokumentasian asuhan keperawatan. Hal ini juga sesuai pernyataan Sochalski (2004), semakin banyak jumlah pasien akan meningkatkan beban kerja dan pada akhirnya akan berpengaruh terhadap kualitas pelayanan. Begitu halnya akibat dari kekurangan tenaga akibat penyebaran dan alokasi yang tidak merata menyebabkan beban kerja meningkat dan risiko terjadi penurunan kualitas pelayanan keperawatan.

Pendokumentasian menjadi kurang efektif disebabkan oleh beban kerja perawat yang bertambah yang disebabkan oleh banyaknya pekerjaan dan berulang karena disebabkan oleh perawat itu sendiri. Maka dari itu, perawat perlu meningkatkan kinerja agar lebih efektif dalam pelaksanaan pendokumentasian asuhan keperawatan dengan memperhatikan faktor-faktor yang mempengaruhi kinerja perawat. 


\section{Pembahasan}

Dokumentasi keperawatan merupakan unsur penting dalam sistem pelayanan kesehatan, karena dengan adanya dokumentasi yang baik informasi mengenai keadaan pasien dapat diketahui secara berkesinambungan. Dokumentasi juga merupakan aspek legal tentang pembuatan asuhan keperawatan, secara lebih spesifik dokumentasi keperawatan dapat berfungsi sebagai sarana komunikasi antar profesi kesehatan, sumber data untuk pengelolaan pasien dan penelitian, sebagai barang bukti pertanggungjawaban dan pertanggung gugatan asuhan keperawatan serta sebagai sarana pemantauan asuhan keperawatan.

Pendokumentasian merupakan bukti pencatatan dan pelaporan perawat yang berguna untuk kepentingan perawat dan tim kesehatan lainnya dalam memberikan pelayanan kesehatan, dan merupakan dasar komunikasi yang akurat dan lengkap secara tertulis. Dokumentasi harus dilakukan segera setelah selesai melakukan kegiatan keperawatan untuk menghindari kealpaan yang tidak disengaja. Pendokumentasian berguna bagi rumah sakit dalam meningkatkan standar akreditasi, sebagai alat komunikasi antar profesi, indikator pelayanan mutu, bukti tanggung jawab dan tanggung gugat perawat, sumber data dan sebagai sarana penelitian. Keberadaan dokumentasi baik berbentuk catatan maupun laporan akan sangat membantu komunikasi antara sesama perawat maupun disiplin ilmu lain dalam rencana pengobatan.

Dokumentasi dibutuhkan untuk keamanan pasien dan menjaga catatannya untuk tetap jelas, akurat, dan komprehensif menjadi bermanfaat bagi perawat dalam pekerjaan sehari-hari. Kualitas dokumentasi keperawatan menunjukkan pemberian perawatan yang baik melalui komunikasi yang efektif di antara perawat dan dengan pemberi perawatan yang lain seperti keluarga pasien.

Tidak lengkapnya dokumentasi asuhan keperawatan berkaitan dengan kinerja perawat dalam melaksanakan pendokumentasian. Mengingat pentingnya pendokumentasian dalam asuhan keperawatan, maka kinerja perawat yang efektif itu penting dalam pelaksanaan pendokumentasian asuhan keperawatan untuk menjaga kesejahteraan pasien dan meningkatkan mutu asuhan keperawatan.

Kinerja merupakan seperangkat hasil yang dicapai untuk merujuk pada tindakan pencapaian serta pelaksanaan suatu pekerjaan yang diminta. Kinerja juga merupakan penampilan hasil kerja individu baik kualitas maupun kuantitas dalam suatu organisasi. Untuk mempertahankan kualitas kinerja organisasi, maka evaluasi terhadap pekerjaan yang telah dilakukan oleh karyawan sangat penting dilakukan sebagai umpan balik sehingga dapat memperbaiki dan meningkatkan kinerja. 
Ada berbagai faktor yang dapat mempengaruhi kinerja perawat. Menurut Rogers dalam Mahmudi, faktor-faktor yang mempengaruhi kinerja adalah:

1. Faktor personal/individu (pengetahuan, skill, kemampuan, motivasi, komitmen)

2. Faktor kepemimpinan (kualitas dalam memberikan dorongan, semangat, arahan dan dukungan yang diberikan manajer dan team leader)

3. Faktor tim (dukungan dan semangat yang diberikan oleh rekan dalam satu tim, kepercayaan terhadap sesama anggota tim, kekompakan dan keeratan anggota tim)

4. Faktor sistem (sistem kerja, fasilitas kerja atau infrastruktur yang diberikan organisasi, proses organisasi dan kultur kinerja organisasi)

5. Faktor kontekstual/situasional (tekanan dan perubahan lingkungan eksternal dan internal).

Menurut Asa'ad (2000), faktor-faktor yang mempengaruhi kinerja perawat adalah karakteristik, motivasi, kemampuan, keterampilan, persepsi, sikap serta lingkungan kerja. Adapun yang termasuk dalam karakteristik perawat meliputi usia, pendidikan, tingkat pengetahuan, masa kerja, serta status. Maka agar kinerja perawat lebih efektif dalam pelaksanaan pendokumentasian asuhan keperawatan, perawat perlu memperhatikan karakteristik, motivasi, kemampuan, keterampilan, persepsi, sikap serta lingkungan kerja.

Menurut asumsi seorang peneliti agar mempunyai kinerja yang baik, seseorang harus mempunyai keinginan yang tinggi untuk mengerjakan serta mengetahui pekerjaannya. Dengan kata lain, kinerja individu dapat ditingkatkan apabila ada kesesuaian antara pekerjaan dengan kemampuan dan motivasinya. Dan juga usia berpengaruh terhadap kinerja perawat, karena semakin berumur seorang perawat memiliki tanggung jawab moral dan loyal terhadap pekerjaan serta lebih terampil karena lama bekerja menjadi perawat.

Seseorang yang mempunyai masa kerja lebih lama akan mempunyai pengalaman, pengetahuan dan keterampilan yang lebih dibanding perawat yang mempunyai masa kerja lebih pendek terhadap tanggung jawabnya. Hal ini sesuai hasil penelitian Lusianah (2008) setiap penambahan masa kerja 1 (satu) tahun maka kualitas dokumentasi proses keperawatan akan mengalami peningkatan sebesar 0,91 setelah dikontrol oleh variabel motivasi kebutuhan kekuasaan, kebutuhan afiliasi, kebutuhan berprestasi, supervisi, pendidikan pengetahuan dan pelatihan.

Mayoritas perawat dengan latar belakang pendidikan DIII Keperawatan. Pendidikan merupakan faktor penting dalam mempengaruhi kinerja seseorang. Berbagai teori dan hasil penelitian menunjukkan bahwa idealnya tingkat pendidikan seseorang akan berbanding lurus dengan kinerjanya. Semakin tinggi tingkat pendidikan seseorang akan semakin tinggi juga pengetahuan, keterampilan, berpikir kritis, mempunyai wawasan yang luas serta harapan dan 
prestasi kerja yang baik. Begitu halnya dengan pendokumentasian yang dilakukan perawat akan semakin lengkap dan baik seiring dengan peningkatan pendidikannya.

Untuk melakukan penerapan asuhan keperawatan dengan baik dan sesuai dengan ilmu pengetahuan yang berkembang, maka perawat harus lebih meningkatkan pengetahuannya baik dalam bidang formal maupun informal demi memberikan pelayanan keperawatan yang berkualitas kepada pasien, sehingga tidak merugikan pasien dalam pelaksanaannya. Pada intinya pengetahuan yang baik dapat menjadi tolak ukur dari suatu pelaksanaan, maka pelaksanaan yang baik dan benar harus didasari oleh pengetahuan dan pengalaman.

Kinerja perawat dalam pendokumentasian asuhan keperawatan tidak terlepas dari motivasi perawat sendiri. Motivasi merupakan pendorong seseorang untuk bergerak mencapai tujuan. Motivasi dipengaruhi secara intrinsik dan ekstrinsik. Faktor intrinsik meliputi prestasi, pengakuan dan penghargaan, tugas itu sendiri dan kewajiban sebagai perawat. Faktor ekstrinsik meliputi gaji/imbalan, jaminan keamanan dan kesehatan, tunjangan, kondisi kerja, kebijakan rumah sakit, hubungan antar pribadi dan reward dari atasan. Selain dua faktor diatas ada faktor lain yang mempengaruhi motivasi perawat yaitu peran kepala ruangan dan supervisor ruangan.

Perawat dalam mendokumentasikan asuhan keperawatan membutuhkan motivasi yang timbul sepenuhnya dari hati. Sehingga untuk menimbulkan motivasi yang baik maka perawat sendiri perlu menyadari kebutuhan dan kepentingan pendokumentasian asuhan keperawatan. Seorang perawat yang memiliki kepatuhan dan motivasi diri yang tinggi, maka pencapaian tujuan akan pelaksanaan dokumentasi asuhan keperawatan akan dilakukan dengan baik. Selain itu dapat meningkatkan pelayanan yang berkualitas dan profesional dalam bidang keperawatan.

Selain motivasi dari diri sendiri, seorang perawat memerlukan orang lain yang memberi motivasi karena dengan kehadiran orang lain akan semakin meningkatkan motivasi dalam diri perawat. Sosok seorang pimpinan atau dalam hal ini kepala perawat diharapkan dapat mengaplikasikan teknik, keterampilan dan pengetahuan termasuk teori motivasi untuk membantu perawat memperoleh apa yang mereka inginkan dari pekerjaan perawatan.

Selanjutnya, hasil penelitian Lusianah (2008) menyatakan bahwa ada hubungan antara kualitas dokumentasi asuhan keperawatan dengan pelatihan, kualitas dokumentasi akan meningkat sebesar 1,60 kali pada perawat yang pernah pelatihan dibanding yang belum pernah pelatihan. Pentingnya pelatihan pendokumentasian bagi perawat memberikan dampak positif terhadap kinerja perawat khususnya dalam melakukan pendokumentasian asuhan keperawatan. Dampak positif pelatihan tersebut harus menjadi bahan pertimbangan manajemen rumah sakit dalam melakukan pelatihan secara periodik untuk memberikan kesempatan bagi perawat yang belum mendapatkan pelatihan untuk lebih meningkatkan pendokumentasian. 


\section{Penutup}

Kesimpulan dan Saran

Dokumentasi keperawatan merupakan unsur penting dalam sistem pelayanan kesehatan, karena dengan adanya dokumentasi yang baik informasi mengenai keadaan pasien dapat diketahui secara berkesinambungan. Pendokumentasian merupakan bukti pencatatan dan pelaporan perawat yang berguna untuk kepentingan perawat dan tim kesehatan lainnya dalam memberikan pelayanan kesehatan, dan merupakan dasar komunikasi yang akurat dan lengkap secara tertulis.

Pendokumentasian yang tidak dilakukan dengan lengkap dapat menurunkan mutu pelayanan keperawatan. Tidak lengkapnya dokumentasi asuhan keperawatan berkaitan dengan kinerja perawat dalam melaksanakan pendokumentasian. Mengingat pentingnya pendokumentasian tersebut, maka perlu diketahui mengenai pentingnya kinerja perawat yang efektif dalam melaksanakan pendokumentasian asuhan keperawatan untuk menjaga kesejahteraan pasien dan meningkatkan mutu asuhan keperawatan dengan memperhatikan faktor-faktor yang mempengaruhi kinerja perawat seperti karakteristik, motivasi, kemampuan, keterampilan, persepsi, sikap serta lingkungan kerja.

\section{Daftar Pustaka}

Bara \& Suryati. (2014). Hubungan motivasi perawat dengan pelaksanaan pendokumentasian asuhan keperawatan di ruang rawat inap RSUD Pasar Rebo. Jurnal Health Quality, 5(1), 9-19.

Budiono, S. B. P. (2015). Konsep dasar keperawatan. Jakarta: Bumi Medika.

Dermawan, D. (2012). Proses keperawatan: Penerapan konsep \& kerangka kerja. Yogyakarta: Gosyen.

Noorkasiani, Gustina, \& Maryam, S. (2015). Faktor-faktor yang berhubungan dengan kelengkapan dokumentasi keperawatan. Jurnal Keperawatan Indonesia, 18(1), 1-8.

Passya, P., Rizany, I., \& Setiawan, H. (2019). Hubungan peran kepala ruangan dan supervisor keperawatan dengan motivasi perawat dalam melakukan dokumentasi keperawatan. Jurnal Keperawatan Raflesia, 1(2), 99-107.

Rohita, T. \& Yetti, K. (2017). Peningkatan kualitas pelayanan keperawatan melalui ronde dan pendokumentasian. Dunia Keperawatan, 5(1), 50-55.

Saputra, M. A. S., Arif, Y., \& Priscilla, V. (2019). Mentoring kepala ruangan meningkatkan kepatuhan perawat dalam pendokumentasian asuhan keperawatan. Jurnal 'Aisyiyah Medika, 3(2), 168-182. 
Saragih, M. (2018). Hubungan pelaksanaan supervisi kepala ruangan dengan kinerja perawat pelaksana dalam pendokumentasian askep. Jurnal Mutiara Ners, 1(1), 65-72.

Simamora, R. (2009). Dokumentasi Proses Keperawatan.

Simamora, R. H., Purba, J. M., Bukit, E. K., \& Nurbaiti, N. (2019). Penguatan Peran Perawat Dalam Pelaksanaan Asuhan Keperawatan Melalui Pelatihan Layanan Prima. JPPM (Jurnal Pengabdian Dan Pemberdayaan Masyarakat), 3(1), 25-31.

Siswanto, H., Hariyani, T. S., \& Sukihananto. (2013). Faktor-faktor yang berhubungan dengan kelengkapan pendokumentasian asuhan keperawatan. Jurnal Keperawatan Indonesia, 16(2), 77-84.

Wirawan, E. A., Novitasari, D., \& Wijayanti, F. (2013). Hubungan antara supervisi kepala ruang dengan pendokumentasian asuhan keperawatan di RSUD Ambarawa. Jurnal Managemen Keperawatan, 1(1), 1-6.

Yanti, R. I. \& Warsito, B. E. (2013). Hubungan karakteristik perawat, motivasi, dan supervisi dengan kualitas dokumentasi proses asuhan keperawatan. Jurnal Managemen Keperawatan, 1(2), 107-114. 